\title{
Morphology and stomach content of the Goldman's diminutive woodrat Nelsonia goldmani (Cricetidae: Neotominae)
}

\author{
M. Ángel León-Tapia ${ }^{1 *}$, Elisa Paulina Zaragoza-Quintana², Claudia Marisol Peralta-Juárez ${ }^{3}$, and Fernando A. Cervantes ${ }^{4}$ \\ ${ }^{1}$ Laboratorio de Sistemática Filogenética, Biología Evolutiva, Instituto de Ecología A.C. Carretera antigua a Coatepec 351 , CP. \\ 09170, Xalapa. Veracruz, México. Email: mal@st.ib.unam.mx (MALT). \\ ${ }^{2}$ Centro de Investigaciones Tropicales, Universidad Veracruzana. Calle José María Morelos 44, CP. 91000 , Xalapa. Veracruz, México. \\ Email: nasuanarik@yahoo.com.mx (EPZQ). \\ ${ }^{3}$ Biología de la reproducción, División de Ciencias Biológicas y de la Salud, Universidad Autónoma Metropolitana, Unidad \\ Iztapalapa. Avenida San Rafael Atlixco 186, CP. 09340, Ciudad de México. México. Email: komportana@hotmail.com (CMPJ). \\ ${ }^{4}$ Instituto de Biología, Departamento de Zoología, Universidad Nacional Autónoma de México. Circuito Deportivo s/n, CP. 04510, \\ Ciudad de México. México. Email: fac@ib.unam.mx (FAC). \\ ${ }^{*}$ Corresponding author
}

Goldman's diminutive woodrat (Nelsonia goldmani) is an endemic rodent that inhabits the temperate and humid environments of the central highlands of Mexico. This species is considered uncommon because of the scarce and dispersed information about specimens collected across the Faja Volcanica Transmexicana. Therefore, it is crucial to generate new information about the basic biology of $N$. goldmani, which so much is unknown thus far. We present the morphological description of the stomach and its content from one specimen of $N$. goldmani. We performed a longitudinal bisection and washing of stomach from one adult male collected at the Natural Park "Las Peñas" in the municipality of Jilotepec, Estado de México, Mexico. The macroscopic structures of the stomach were described by observation in a stereoscopic microscope. The stomach content was mounted on sliders and its components were identified and photographed with an optical microscope. According to the gastric glandular epithelium distribution, N. goldmani have a bilocular-discoglandular stomach with a characteristic fornix ventricularis slightly elongated horizontally. The stomach content was composed by several plant items: epidermal tissues of steam and leaves of angiosperms, pollen of gymnosperms, spores of ferns, fungi and animal tissue like mouth appendages and legs of insects. The stomach morphology was similar to the $N$. neotomodon and the peromyscine Neotomodon alstoni described previously, but the flattened and elongated fornix ventricularis found in N. goldmani was distinctive. Nonetheless, this structure can vary between individuals and mainly depends of the amount of food before dissection. The plant material found in the stomach was similar to that reported in other rodents that inhabit in similar environments to the highlands of central Mexico, such as Peromyscus aztecus, P. difficilis and Reithrodontomys fulvescens.

La rata enana michoacana (Nelsonia goldmani) es un roedor endémico que habita en los ambientes templados y húmedos de la zona montañosa del centro de México. Esta especie es considerada como poco común debido a la escasa información disponible para los especímenes colectados en la Faja Volcánica Transmexicana. Por lo tanto, es indispensable generar información nueva de la biología básica de N. goldmani mucha de la cual se desconoce hasta el momento. Presentamos la descripción morfológica del estómago y su contenido en un ejemplar de $N$. goldmani. Se realizó un corte longitudinal y un lavado del estómago de un macho adulto colectado en el Parque Natural "Las Peñas" en el Municipio de Jilotepec, Estado de México, México. Se describieron las estructuras macroscópicas del estómago por observación en un microscopio estereoscópico. El contenido estomacal fue montado en laminillas y sus componentes fueron identificados y fotografiados en un microscopio óptico. Según la distribución del epitelio glandular gástrico, N. goldmani tienen un estómago bilocular-discoglandular con un característico fórnix ventricularis ligeramente alargado horizontalmente. El contenido estomacal estuvo compuesto por varios elementos vegetales: tejido epidérmico de tallos y hojas de angiospermas, polen de gimnospermas, esporas de helechos, hongos y tejido animal de aparatos bucales y patas de insectos. La morfología estomacal fue similar a la de N. neotomodon y el peromyscino Neotomodon alstoni descritos previamente, pero el fórnix ventricularis aplanado y alargado encontrado en $N$. goldmani fue distintivo. Sin embargo, esta estructura puede variar entre individuos y depende principalmente de la cantidad de alimento antes de la bisección. El material vegetal estomacal encontrado fue similar al reportado en otros roedores que habitan en ambientes similares a las zonas altas del centro de México como Peromyscus aztecus, P. difficilis y Reithrodontomys fulvescens.

Keywords: Cloud forest; Estado de México; feeding; rare species; rodentia.

(c) 2018 Asociación Mexicana de Mastozoología, www.mastozoologiamexicana.org

\section{Introduction}

Mexico hosts a wide diversity of rodents with an estimated number of 233 species, which 140 belongs to the family Cricetidae (Ramírez-Pulido et al. 2014). Nevertheless, most of these species have scarce information about its basic biology, such as demography, ecological role in their communities, and history life, to mention some examples (Fernández et al. 2014). Furthermore, some of these rodents are listed under some category of extinction risk, and for which the lack of information is critical, for instance, for the develop- ment of plans aimed to their habitat conservation (SEMARNAT 2010).

One of these species is the Goldman's diminutive woodrat Nelsonia goldmani Merriam 1903, an endemic taxon that inhabits temperate and humid regions of highlands of central Mexico. It is considered an uncommon species due to few specimens collected after being discovered and its fragmented geographical distribution across the biogeographical region known as Faja Volcánica Transmexicana (León-Tapia 2013). As well, this species is under "Special 
Protection" by the NOM-059-SEMARNAT-2010 (SEMARNAT 2010) in Mexico and "Endangered" by the by the International Union for Conservation of Nature (IUCN; ÁlvarezCastañeda and Castro-Arellano 2008).

Most of the basic aspects of the biology of this species is unknown, mainly related to the few biological material available of this rodent and making difficult to carry out some studies such as particular internal morphology and the diet. Therefore, in this study we describe for first time the macroscopic stomach morphology and its content from one individual of N. goldmani in order to provide information related to the digestive system morphology and the food items consumed by the rodent.

\section{Materials and Methods}

One adult male of N. goldmani was collected with the authorization FAUT-0002 on October 162010 and vouchered in the Colección Nacional de Mamíferos (CNMA 46291), at the Natural Park "Las Peñas", Jilotepec, Estado de México, Mexico (Figure 1; León-Tapia 2013). The vegetation at the collecting locality was mainly oak forest (Quercus sp.) with some areas with fir and montane cloud forests (Engstrom et al. 1992; Carleton et al. 2002).
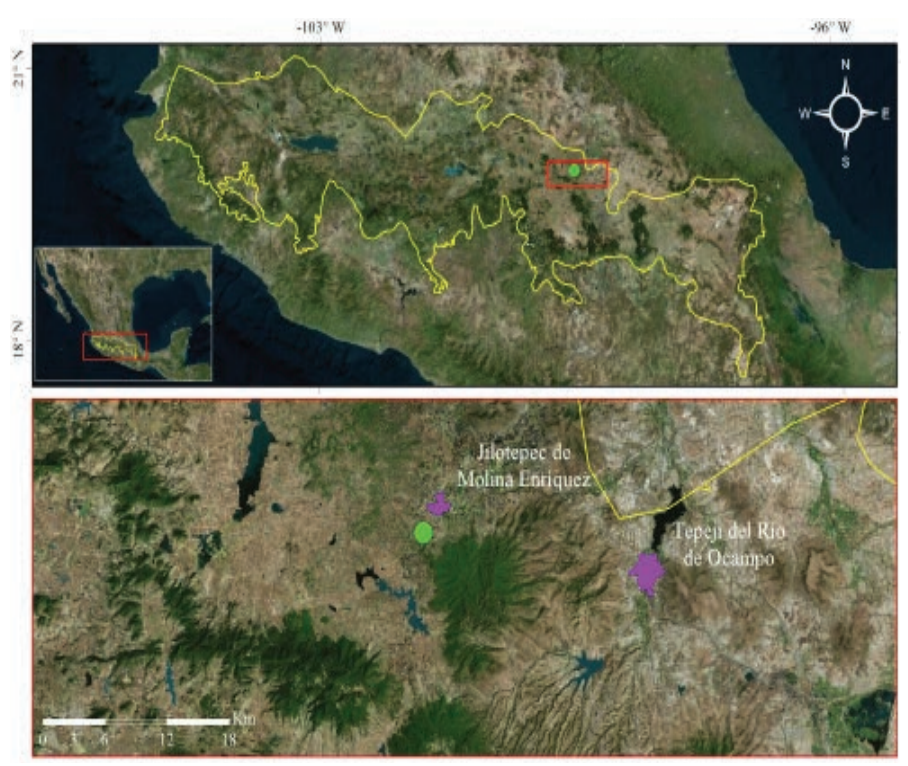

Figure 1. Geographic location of the specimen of Nelsonia goldmani (CNMA 46291) collected at the Faja Volcánica Transmexicana in México (yellow polygon). The green dot shows the collecting locality of the specimen close to the main towns of the region in purple polygons.

From this specimen we removed the stomach in situ cutting the end of the esophagus and duodenum, immediately preserved it in $70 \%$ alcohol, and posteriorly stored it at $-72{ }^{\circ} \mathrm{C}$. For the stomach description and the terminology of the structures, the classical methodology stated by Careton (1973) was used. The stomach was placed in a laboratory dish and a ventral bisection was made in a horizontal plane, the stomach content was extracted with $70 \%$ alcohol and conserved at $4{ }^{\circ} \mathrm{C}$ for posterior analyses. We carried out the observation of stomach in a stereoscopic microscope (Nikon SMZ445) and the illustration of stomach and structures was made.
The stomach content was analyzed according to the procedure used to determinate the diet of Peromyscus difficilis (Morales-Medina 2010; Peralta-Juárez 2015). The stomach material was disaggregated on a glass slide, covered with a coverslip and sealed for its preservation. Subsequently, observations were carried out in an optic microscope Zeiss Axiophot 7082 in order to locate the stomach items. During this process, pictures were taken with a digital microscope camera Moticam 2000 and the software Motic Image Plus 2.0. We used different colored filters in addition to black and white filters for color investment in order to highlight the desired stomach items. Finally, the pictures were edited for emphasizing some structural features of such items in order to taxonomically identify them using specialized literature (Linconff 1988; Andrews and Caballero 1989; Phillips 1991; Guzmán 1998; Palacios-Vargas et al. 2014).

\section{Results}

The specimen of $N$. goldmani was taxonomically identified by both external and internal characteristics (Figure 2). According to the color nomenclature (Ridgway 1912), we determined that it was dark dorsally (buffy olive at tips and blackish slate at base), white ventrally, laterally olive lake and the hind feet white with olive lake color at the upper parts. The tail was large with long liver brown hairs dorsally

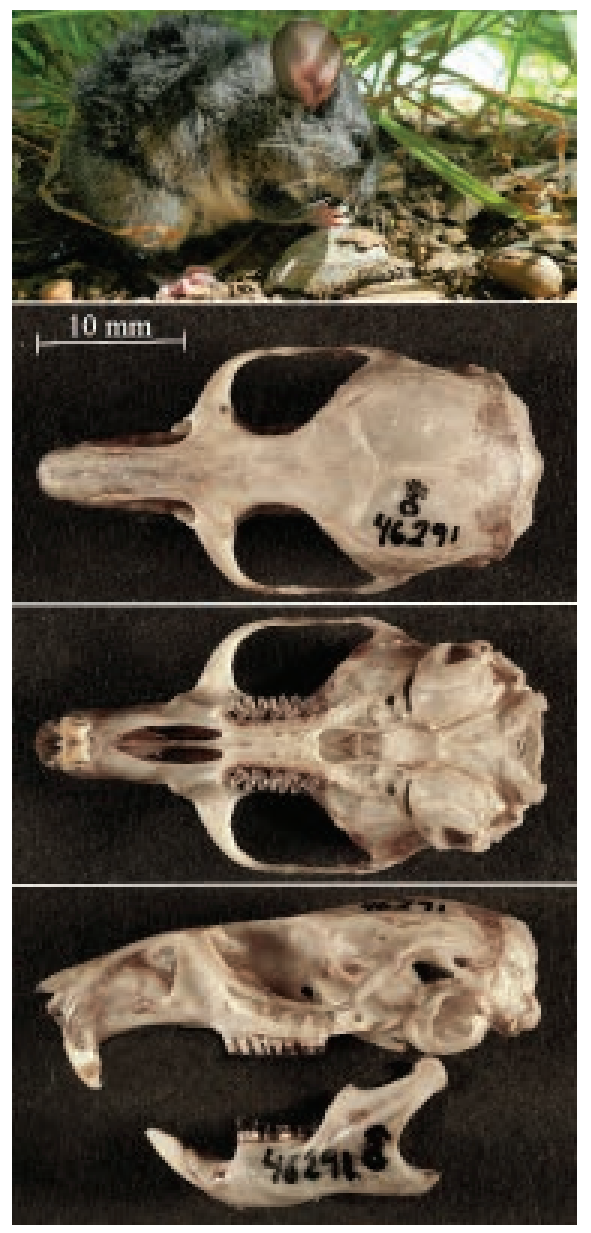

Figure 2. Photographs of the Nelsonia goldmani (CNMA 46291). From top to bottom: individual feeding on seeds of oak (Quercus sp.), dorsal, ventral and lateral view of the skull. 
and cream color ventrally, but no completely bicolored and with a distinctive terminal tuft of hair. The external measurements in $\mathrm{mm}$ were: total length 260 , tail length 140 , hind foot length 25 and ear length 24 . The skull was flattened with the presence of the diagnostic anteorbital zygomatic notch and the singular prismatic molar pattern. The cranial measurements according to González-Cózatl et al. (2016) were: greatest length of skull 32.8, length of rostrum 13.11 , breadth of zygomatic plate 3.76 , mastoid breadth 14 , zygomatic breadth 16.67, interorbital constriction 4.63, breadth of rostrum 5.51, width of interparietal bone 10.24, breadth across molars 6.33 and depth of skull 10.39.

Stomach description. According to the gastric glandular epithelium arrangement, N. goldmani has a bilocular-discoglandular stomach (Figure 3). The incisura angularis is deep and proyected beyond the esophageal opening forming the stomach bilocular condition well defined. The fornix ventricularis archs are located further from the esophageal opening and slightly curved to the esophagus. The size of corpus, mainly in fornix ventricularis section, is elongated horizontally. The antrum walls are muscular, more visible near the pyloric opening. A bordering fold surrounds the glandular epithelium, and restricted by a small curved area

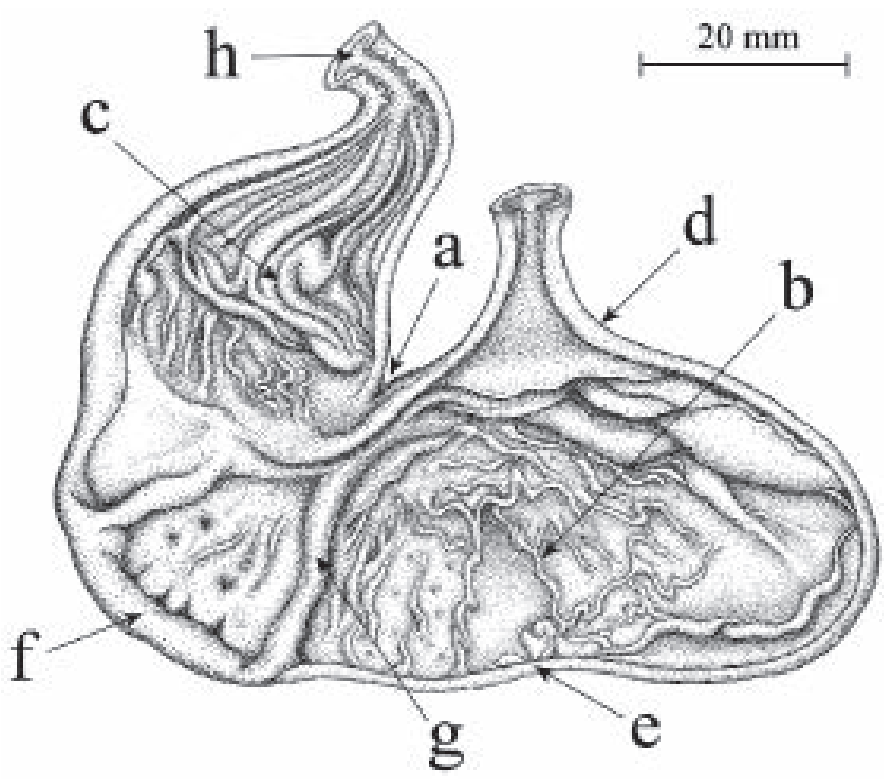

Figure 3. Illustration of the macroscopic bilocular-discoglandular stomach structures of the Nelson and Goldman's woodrat Nelsonia goldmani (CNMA 46291). a) incisura angularis, b) corpus, c) antrum, d) fornix ventricularis, e) cornified squamous epithelium, f) glandular epithelium, g) bordering fold, and h) anterior end of duodenum.

on the left side of the grandular zone at the bottom of the stomach. The cornified squamose epithelium coats the remaining areas of the antrum and corpus.

Stomach content. Several food items of plant origin were detected in the stomach content, such as epidermal tissue mainly consisting of stems and leaves, pollen of gimnosperms and spores of ferns and fungi. Likewise, animal tissues were observed, such as mouth appendages and legs of insects (Figure 4). The plant tissues were most frequent in the analyzed samples, and the spores were scarce.

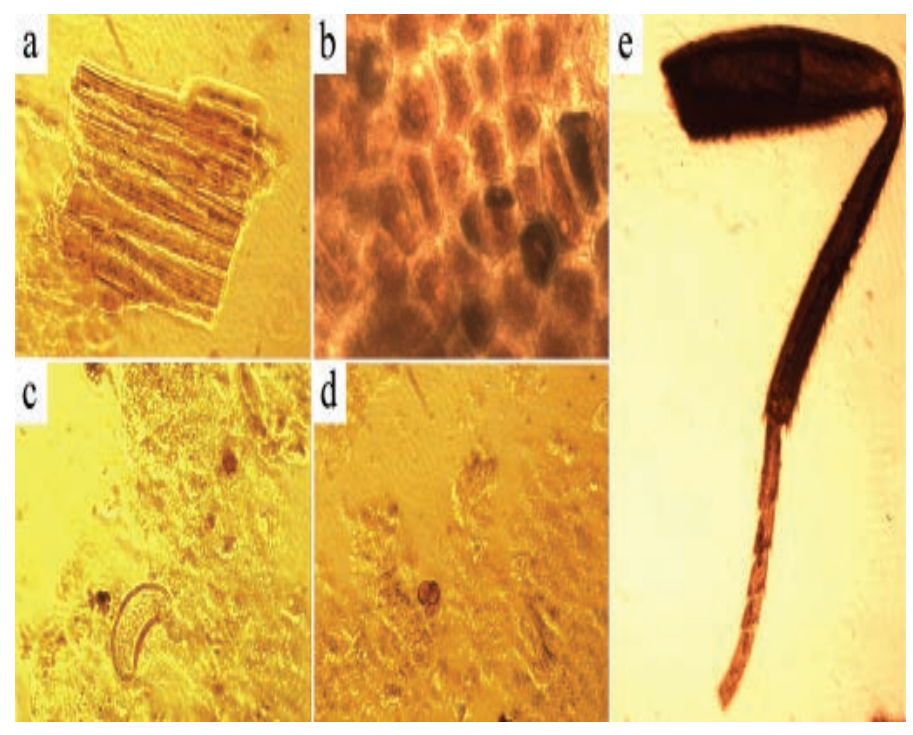

Figure 4. Pictures from optical microscopy at 40x of food items found in a stomach of the Nelson and Goldman's woodrat Nelsonia goldmani (CNMA 46291). a) epidermal tissue from stems, b) epidermal tissue from leaves, c) fern spores, d) gymnosperms pollen, and e) leg of an insect.

\section{Discussion}

The stomach morphology of N. goldmani was similar to its sister species N. neotomodon, described previously by Careton (1973), with the exception of the fornix ventricularis, which is further flattened and elongated. Nonetheless, it has been shown that this structure can vary between individuals and mainly depends of the amount of food before dissection. Hooper (1954) pointed out that some stomach structures like the pronounced incisura angularis in rodents as N. goldmanik, with a bilocular stomach, could increase the area for intensive mixing and reworking of the food bolus. However, this information is limited to make inferences about feeding.

Regarding to the stomach content, it was possible to identify that this individual ingested mainly plant items. Similarly, the insect items could indicate that were occasionally ingested by the specimen. These results were similar to the observations reported for $N$. neotomodon from one specimen from San Luis, where the mainly food items were a green mass with the appearance of fir (Pseudotsuga menziesii) or junipers (Juniperus sp.) needles (Hooper 1954).

Prior to the capture of the specimen of N. goldmani, we observed the individual feeding on lichens on the bark of trees and photographed it eating seeds of Quercus sp. (Figure 2). These observations could indicate that this species likely eats a wide plant resource available in the locality. However, it is indispensable to carry out specific studies throughout the years in order to have an approximation about its diet.

The diet for the two species of the genus Nelsonia is unknown mainly due to the difficulties to capture these rodents. Even so, the findings in this study contribute to the knowledge of the basic biology of N. goldmani and the results are comparable to those reported for other rodent species that inhabit environments apparently similar in the 
highlands of central Mexico, such as Peromyscus aztecus, $P$. difficilis and Reithrodontomys fulvescens. These rodents feed preferentially upon plant material of different composition according to the conservation condition of their habitat (Vázquez et al. 2004; Peralta-Juárez 2015).

\section{Acknowledgments}

We thank to Consejo Nacional de Ciencia y Tecnología for the scholarship 239887. To Secretaría de Turismo de Jilotepec and B. Sánchez-Vázquez for their kindly help and disposition. To C. Luna-Aranguré and Andrea Ballen for the stomach illustration. To H. Méndez for his support in the identification of spores. To A. Castro-Campillo for her aid in laboratory.

\section{Literature cited}

Álvarez-Castañeda, S. T., and I. Castro-Arellano. 2008. Nelsonia goldmani. In: IUCN 2017. The IUCN Red List of Threatened Species. Version 2017.3. www.iucnredlist.org. Accessed May 292018.

Álvarez-Castañeda, S. T., and N. Gónzalez-Ruiz. 2018. Spanish and English vernacular names of mammals of North America. Therya 9: 73-84.

Andrews, K., and R. Caballero. 1989. Guía para el estudio de Órdenes y Familias de Insectos de Centroamérica. Escuela Agrícola Panamericana. Zamorano, Honduras.

Carleton, M. D. 1973. A survey of gross stomach morphology in new world Cricetidae (Rodentia, Muroidea), with comments in functional interpretations. Micellaneous Publications Museum of Zooology, University of Michigan 146:1-43.

Carleton, M. D., O. Sánchez, and G. U. Vidales. 2002. A new species of Habromys (Muroidea: Neotominae) from Mexico, with generic review of species definitions and remarks on diversity patterns among Mesoamerican small mammals restricted to humid montane forests. Proceedings of the Biological Society of Washington 115:488-533.

Engstrom, M. D., O. Sánchez-Herrera, and G. Urbano-Vidales. 1992. Distribution, geographic variation, and systematic relationships within Nelsonia (Rodentia: Sigmodontinae). Proceedings of the Biological Society of Washingston 105:867-881.

Fernández, J. A., M. S. Hafner, D. J. Hafner, and F. A. Cervantes. 2014. Conservations status of rodents of the families Geomyidae and Heteromyidae of Mexico. Revista Mexicana de Biodiversidad 85:576-588.

González-Cózatl, F. X., R. M. Vallejo, and E. Arellano. 2016. First record of Nelsonia goldmani in the state of Morelos, Mexico. Revista Mexicana de Biodiversidad 87:545-547.

GuZMÁN, G. 1998. Inventorying the fungi of Mexico. Biodiversity and Conservation 7:369-384. URL: https://link.springer.com/ article/10.1023/A:1008833829473

Hooper, T. E. 1954. A synopsis of the Cricetine rodent genus Nelsonia. Occasional Papers of the Museum of Zoology, University of Michigan Press 558:1-12.

LÉON-TAPIA, M. A. 2013. Ubicación filogenética con caracteres moleculares de la rata de monte (Nelsonia goldmani), endémica del Eje Neovolcánico Transversal. Tesis de Maestría, Instituto de Biología, Universidad Nacional Autónoma de México. Ciudad de México, México.
Lincoff, G. H. 1988. The Audubon Society field Guide to North American Mushrooms. Alfred A. Knopf. New York, U. S. A.

MerRIAM, C. H. 1903. Four new mammals, including a new genus (Teanopus), from México. Proceedings of the Biological Society of Washington 16:79-82.

Morales-Medina, X. 2010. Contribuciones para la facilitación de los estudios sobre dieta en ratones silvestres, tomando como ejemplo al género Peromyscus. Tesis de Maestría, División de Ciencias Biológicas y de la Salud, Universidad Autónoma Metropolitana, Unidad Iztapalapa. México.

Palacios-Vargas, J. G., B. E. Mejía-Recamier, and A. De Oyarzabal. 2014. Guía ilustrada para los artrópodos edáficos. Las Prensas de Ciencias, Universidad Nacional Autónoma de México. Ciudad de México, México.

Peralta-Juárez, C. M. 2015. Dieta de Peromyscus difficilis (Rodentia: muridae) en un bosque templado en el parque nacional desierto de los leones. Tesis de Maestría, División de Ciencias Biológicas y de la Salud Unidad Iztapalapa, Universidad Autónoma Metropolitana, Ciudad de México, México.

PhILliPs, R. 1991. Mushrooms of North America. Little, Brown and Company. Boston, U.S. A.

Ramírez-Pulido, J., N. González-Ruiz, A. L. Gardner, and J. ArroyoCABRAles. 2014. List of recent land mammals of Mexico, 2014. Special Publications of Museum of Texas Tech University 63:1-76.

RIDGWAY, R. 1912. Color standards and color nomenclature. Privately Published. Washington, U. S. A.

Secretaria de Medio Ambiente y Recursos Naturales. 2010. Norma Oficial Mexicana NOM-059-SEMARNAT-2010, Protección ambiental-especies nativas de México de flora y fauna silvestres-categorías de riesgo y especificaciones para su inclusión, exclusión o cambio-lista de especies en riesgo. Diario Oficial de la Federación (segunda sección). México. 30 de diciembre de 2010.

Vázquez, L., G. N. Cameron, and R. A. Medellín. 2004. Characteristics of diet of Peromyscus aztecus and Reithrodontomys fulvescens in montane western Mexico. Journal of Mammalogy 85:196-205.

Associated editor: Pablo Teta

Submitted: June 14, 2018; Reviewed: July 17, 2018;

Accepted: August 25, 2018; Published on line: August 30, 2018. 